\title{
Tumorsphere as an effective in vitro platform for screening anti- cancer stem cell drugs
}

\author{
Che-Hsin Lee ${ }^{1,2}$, Cheng-Chia Yu ${ }^{3,4,5}$, Bing-Yen Wang ${ }^{6,7,8}$ and Wen-Wei Chang ${ }^{9,10}$ \\ ${ }^{1}$ Graduate Institute of Basic Medical Science, School of Medicine, China Medical University, Taichung City, Taiwan \\ 2 Department of Microbiology, School of Medicine, China Medical University, Taichung City, Taiwan \\ ${ }^{3}$ School of Dentistry, Chung Shan Medical University, Taichung City, Taiwan \\ ${ }^{4}$ Department of Dentistry, Chung Shan Medical University Hospital, Taichung City, Taiwan \\ ${ }^{5}$ Institute of Oral Sciences, Chung Shan Medical University, Taichung City, Taiwan \\ ${ }^{6}$ Institute of Medicine, Chung Shan Medical University, Taichung City, Taiwan \\ 7 Division of Thoracic Surgery, Department of Surgery, ChangHua Christian Hospital, ChangHua County, Taiwan \\ ${ }^{8}$ School of Medicine, National Yang-Ming University, Taipei City, Taiwan \\ ${ }^{9}$ School of Biomedical Sciences, Chung Shan Medical University, Taichung City, Taiwan \\ ${ }^{10}$ Department of Medical Research, Chung Shan Medical University Hospital, Taichung City, Taiwan \\ Correspondence to: Wen-Wei Chang, email: changww@csmu.edu \\ Keywords: cancer stem cells, tumorsphere, targeting therapy, drug screening \\ Received: June 11,2015 Accepted: October 14, $2015 \quad$ Published: October 31, 2015
}

This is an open-access article distributed under the terms of the Creative Commons Attribution License, which permits unrestricted use, distribution, and reproduction in any medium, provided the original author and source are credited.

\section{ABSTRACT}

Cancer stem cells (CSCs) are a sub-population of cells within cancer tissues with tumor initiation, drug resistance and metastasis properties. CSCs also have been considered as the main cause of cancer recurrence. Targeting CSCs have been suggested as the key for successful treatment against cancer. Tumorsphere cultivation is based on culturing cancer cells onto ultralow attachment surface in serum-free media under the supplementation with growth factors such as epidermal growth factor and basic fibroblast growth factor. Tumorsphere cultivation is widely used to analyze the self-renewal capability of CSCs and to enrich these cells from bulk cancer cells. This method also provides a reliable platform for screening potential anti-CSC agents. The in vitro anti-proliferation activity of potential agents selected from tumorsphere assay is more translatable into in vivo anti-tumorigenic activity compared with general monolayer culture. Tumorsphere assay can also measure the outcome of clinical trials for potential anti-cancer agents. In addition, tumorsphere assay may be a promising strategy in the innovation of future cancer therapeutica and may help in the screening of anti-cancer small-molecule chemicals.

\section{INTRODUCTION}

Cancers consist of several varieties of cell types such as cancer cells, stroma cells, endothelial cells, and immune cells; cancers are considered as tissues with heterogeneity [1]. Phenotypic and functional diversity arise among cancer cells. In the past two decades, the identification of cancer stem cells (CSCs) and the power of these cells in the establishment of new tumors during experimental implant in animal hosts [2] enabled CSCs to gain much attention in the field of cancer research.
CSCs are a sub-population of cancer cells with properties of tumor initiation. CSC propagate through asymmetric division; similarly, differentiated daughter cells form tumor bulk [3] and normal stem cells differentiate into multiple cell types within a tissue or organ via asymmetric division. CSCs hijack the cellular mechanisms in the maintenance of self-renewal property of normal stem cells to maintain the high tumorigenicity of these cancer cells [4]. CSCs targeting has been considered as the key for successful cancer treatment with the increasing relapse rate of cancers toward current chemo or radiotherapy and the link between CSCs and drug resistance of cancers [5]. 
Table 1: Identified CSC markers in several types of cancers

\begin{tabular}{|c|c|c|}
\hline Cancer Type & CSC markers & Reference \\
\hline AML & $\mathrm{CD} 34^{+} \mathrm{CD} 38^{-}$ & 6 \\
\hline brain & $\mathrm{CD}_{133}{ }^{+}, \mathrm{CD}_{4} 4^{+}$ & 7 \\
\hline breast & $\mathrm{CD} 24^{-/ \text {low }} \mathrm{CD}_{4} 4^{+}, \mathrm{ALDH}^{\text {bright }}, \mathrm{CD} 133^{+}, \mathrm{CD} 221^{+}$ & $8-11$ \\
\hline colon & $\mathrm{CD}_{133^{+}}, \mathrm{CD}_{4} 4^{+}, \mathrm{CD} 24^{+}, \mathrm{CD} 166^{+}, \mathrm{Lgr}^{+}, \mathrm{ALDH}^{\text {bright }}$ & 12 \\
\hline head and neck & $\mathrm{CD} 133^{+}, \mathrm{CD}_{4} 4^{+}, \mathrm{ALDH}^{\text {bright }}, \mathrm{SP}, \mathrm{GRP} 78^{+},{\mathrm{c}-\mathrm{Met}^{+}}^{+}$ & 13 \\
\hline liver & $\mathrm{CD} 133^{+}, \mathrm{CD} 90^{+}, \mathrm{EpCAM}^{+} / \mathrm{CD}_{4} 4^{+}, \mathrm{CD} 3^{+}, \mathrm{SP}$ & 14 \\
\hline lung & $\mathrm{CD}_{4} 4^{+}, \mathrm{CD} 133^{+}, \mathrm{CD} 117^{+}, \mathrm{CD} 87^{+}, \mathrm{SP}, \mathrm{ALDH}^{\text {bright }}$ & 15 \\
\hline ovarian & $\mathrm{SP}, \mathrm{CD} 133^{+}, \mathrm{CD}_{4} 4^{+}, \mathrm{CD} 24^{+}, \mathrm{CD} 117^{+}, \mathrm{EpCAM}^{+}, \mathrm{ALDH}^{\text {bright }}$ & 16 \\
\hline pancreatic & $\mathrm{CD} 44^{+} / \mathrm{CD} 24^{+} / \mathrm{ESA}^{+}, \mathrm{CD}_{133}{ }^{+}, \mathrm{c} \mathrm{Met}^{+}, \mathrm{ALDH}^{\text {bright }}$ & 17 \\
\hline prostate & 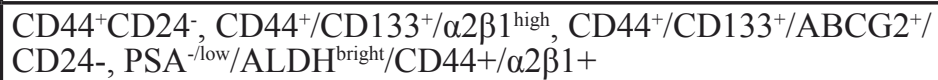 & 18 \\
\hline
\end{tabular}

\section{DISCOVERY, CHARACTERISTICS AND ISOLATION METHODS OF CANCER STEM CELLS}

The first experimental description of CSCs was demonstrated in a leukemia study in 1997 by John Dick's group [6]. Only a subset of acute myeloid leukemia (AML) cells could transfer AML from patients to nonobese diabetic/severe combined immunodeficient (NOD/ SCID) mouse hosts [6]. These AML-initiating cells were found to carry the cell surface markers of $\mathrm{CD} 34^{+} \mathrm{CD} 38^{-}$ similar to normal haematopoietic stem cells (HSCs) [6], implying that normal HSCs are the cell origin of leukaemic transformation. The identification of AMLCSCs led scientists to search corresponding CSCs in solid tumors, including brain [7], breast [8-11], colon [12], head and neck [13], liver [14], lung [15], ovarian [16], pancreatic [17], and prostate [18], as summarized in Table 1.

The characteristics of CSCs include tumor initiation, resistance to chemo or radiotherapy, metastasis and involvement of tumor vascularization. The propagation of CSCs to maintain the tumor initiation ability refers to self-renewal of CSCs [3] and signaling pathways in maintenance of self-renewal of normal stem cells are also found to be activated in CSCs, including B lymphoma Mo-MLV insertion region 1 homolog (Bmi1) [19], sex determining region Y-box 2 (Sox2 )[20], Wnt/ $\beta$-catenin [21] and octamer-binding transcription factor 4 (Oct4) [22]. CD24-CD44+ breast CSCs were noted to be more resistant to radiation than non-CSCs [23]; and these cells not only survived radiation treatment but also induced into the active cell cycle to proliferate [24]. CD133 ${ }^{+}$pancreatic
CSCs were demonstrated to be resistant to gemcitabineinduced apoptosis [25], the drug frequently used to treat pancreatic cancer patients. We have demonstrated that silencing of heat shock protein 27 (Hsp27) or treatment of HSP inhibitors potentiated breast CSCs to the suppressive effect of Hsp90 inhibitors [26]. Recent study also reveals that tumor transforming factor (TGF)- $\beta$ signaling in squamous cell carcinoma CSCs enhanced glutathione metabolism and decreased the efficacy of anti-cancer drugs [27]. The invasive phenotype of cancer cells is driven through the epithelial-mesenchymal transition (EMT) program [28]. Induction of EMT in immortalized human mammary epithelial cells by EMT-related transcriptional factors (twist or snail) or TGF- $\beta 1$ could increase the expression of CD24-CD44 ${ }^{+}$[29].CD24-CD44 ${ }^{+}$ breast CSCs isolated from primary human breast cancer specimens and expressed markers associated with EMT [29]. The direct regulation of Bmil by twist, one of the regulatory transcriptional factors in EMT process, has been demonstrated that these two molecules could cooperate to promote the EMT process and tumor initiation capacity of head and neck squamous carcinoma cells (HNSCC) [30]. We have previously shown that Hsp27 regulated the self-renewal of breast CSCs and controlled their invasive phenotype through downregulation of snail [31]. Wettstein et al. further supported our finding by demonstrating that the inhibition of Hsp27 promoted snail degradation and prevented TGF- $\beta$ induced EMT [32]. Hermann et al. discovered that CXCR4 expression in $\mathrm{CD} 133^{+}$pancreatic CSCs determined the metastatic potential to liver without affecting their tumor initiation capability [33], which presented the concept of metastatic CSCs. Recently, Gao et al. discovered that knockdown of CD44, a marker for 
CSCs of hepatocellular carcinoma (HCC), diminished the metastatic ability in the experimental mouse model [34]. This work demonstrated the function of CSC marker in the regulation of metastasis. CSCs could also contribute to tumor vascularization. The $\mathrm{CD}_{4} 4^{+}$ovarian cancer cells have been determined to transdifferentiate into endothelial progenitor cells (EPCs). When CD44+ ovarian cells were cultured with Matrigel, these cells expressed EPC marker CD34 through a vascular endothelial growth factor (VEGF) independent inhibitor of nuclear factor kappa-B kinase $\beta$ (IKK $\beta$ )-dependent mechanism [35]. Wang et al. observed that a subpopulation of $\mathrm{CD}_{133^{+}}$glioma CSCs expressed the marker of vascular endothelial-cadherin (CD144), which displayed characteristics of endothelial progenitors [36]. Blocking the VEGF signaling pathway suppressed the maturation of these tumor endothelial progenitors $\left(\mathrm{CD}_{133}{ }^{+} \mathrm{CD} 144^{+}\right)$into endothelium; and the inhibition of Notch signaling pathway abolished the transition of glioma CSCs into endothelial progenitors [36]. Vasculogenic mimicry (VM) is another type of tumor vascularization that forms vessel-like channels by tumor cells without the involvement of endothelial cells [37]. Liu et al. demonstrated that CD133 ${ }^{+}$MDA-MB-231 cells, which have been demonstrated as CSCs in Brcal-deficient mouse mammary tumors [38], formed VM structures in triple negative breast cancer tissues [39]. These reports suggested that CSCs may support tumor vascularization through direct transdifferentiation into endothelial cells, EPCs or through the VM mechanism.

CSCs are considered as a small population of cancer cells within a bulk tumor mass. The first and essential step in studying CSCs is to separate them from the entire tumor population. Fluorescence-activated cell sorting (FACS) is the first method to isolate CSCs and is based on the differential expression of cell surface markers by labeling CSCs with fluorescent-conjugated antibodies and isolating by FACS cell sorter. The identification of AML-CSCs or breast CSCs by CD34 ${ }^{+} \mathrm{CD} 38^{-}$[6] or CD24 $\mathrm{CD}_{4} 4^{+}$[8] surface markers, respectively, is the two top known examples. In addition to surface markers, FACS could also be applied to fluorescent-based substrates such as BODIPY aminoacetaldehyde (Aldefluor substrate) for isolation of cells with intracellular ALDH activity (ALDH ${ }^{\text {bright }}$ cells); these subpopulation of cancer cells have been identified as CSCs in several types of cancers [40]. Side population (SP) analysis is also a method in applying FACS isolation of CSCs, which is based on the efflux of Hoechst 33342 fluorescent dye [41]. Although SP analysis is considered as an alternative marker to isolate CSCs with no known surface markers, Broadley et al. reported that SP cells were insufficient for CSC phenotype in glioblastoma multiforme [42]. The other fluorescencebased isolation of CSCs is dependent on the cellular proteasome activity. Vlashi et al. first demonstrated that the use of the fluorescence protein ZsGreen fused to the carboxylterminal degron of ornithine decarboxylase to differentiate the intracellular proteasome activity among cells, CSCs of human glioma or breast cancer cells displayed a phenotype of reduced $26 \mathrm{~S}$ proteasome activity [43]. The reduced $26 \mathrm{~S}$ proteasome activity of CSCs has been also observed in HNSCCs [44]. Although FACS-based isolation of CSCs seems to be promising, the limitation or disadvantage of CSC isolation by FACS is the availability of fluorescent-conjugated antibodies or substrates as well as the high cost of cell sorter. FACS-based isolation of potential CSCs requires further functional examinations to approve their CSC properties, such as in vivo tumorigenicity, in vitro drug resistance, cell invasion behavior, or self-renewal capability through tumorsphere assay.

Compared with FACS-based method, isolation of CSCs through tumorsphere cultivation does not require a background knowledge on cell surface markers. Tumorsphere cultivation for CSC isolation was first described by Singh et al. in brain tumors [45], a culture method originally used to isolate neural stem cells [46]. In the study of neural stem cells, the formation of neurospheres was considered as an assay of selfrenewal capability according to further examination of the multilineage differentiation ability of these floating spheroid cells [46]. This stem cell cultivation method is based on plating single cell suspension at a proper cell density on ultralow attachment surface with the serumfree culture medium in supplementation with several defined growth factors such as epidermal growth factor (EGF), basic fibroblast growth factor (bFGF) and neural survival factor [47]. Tumorspheres derived from human primary brain tumor specimens expressed markers of neural stem cells (CD133 and nestin) and could further induce multilineage differentiation into neuronal cells or astrocytes . In 2005, Ponti et al. applied the mammosphere cultivation method in in vitro propagation of mammary stem/progenitor cells to isolate breast CSCs from primary breast cancer specimens and established human breast cancer cell lines [48]. Mammospheres derived from breast cancer cells expressed CD24-CD44+ markers and displayed a great tumorigenicity when xenotransplanted into mammary fat pads of NOD/SCID mice [48]. To date, tumorspheres are successfully cultured from varieties of cancers such as colon [49], HNSCC [50], lung [51], pancreatic [52], prostate [53], melanoma [54], ovarian [55] and thyroid [56] cancer. Tumorsphere cultivation is widely accepted as a functional assay of self-renewal property of CSCs [47].

\section{TUMORSPHERES DISPLAY ALL THE CHARACTERISTICS OF CANCER STEM CELLS}

Tumorspheres derived from cancer cells have been proven to display characteristics of CSCs. Dieter et al. applied tumorsphere cultivation to analyze the 
cellular heterogeneity within colon CSCs [57]. The frequency of sphere-forming cells in the entire human primary colon cancer cells was low but the formed colon tumorspheres displayed a significant tumorigeneicity when xenotransplanted into the kidney capsule of immunodeficient IL2RG ${ }^{-/-}$mice compared with fresh tumor cells derived from the respective original tumor sample [57]. Coulon et al. also demonstrated that human neuroblastoma cells selected by tumorsphere cultivation displayed increased in vivo tumorigenicity in orthotopic microenvironment compared with cells propagated in the presence of $10 \%$ serum [58]. In the genetically engineered mouse model of breast cancer, 1000 dissociated cells from 3-week-old tumorspheres derived from tumors of mouse mammary tumor virus (MMTV)-Neu or MMTVWnt mice could form tumors when transplanted into the mammary fat pads of $\mathrm{Rag}^{-/ /}$mice [59]. Morrison et al. also demonstrated that tumorsphere forming cells in murine ling cancer cell lines were more tumorigenic than adherent cells in the syngeneic host [60]. These reports demonstrate that tumorsphere cells display capability in tumor initiation. CSCs are known to display highly invasive phenotype, which is driven through the EMT program [61]. Lichner et al. found that tumorspheres derived from renal cell carcinoma cells showed elevated expression of mesenchymal markers [62]. Tumorspheres derived from human ovarian cancer cell lines displayed a greater in vitro invasive ability and in vivo metastasis than their parental counterparts [55]. We have also demonstrated that tumorspheres derived from HNSCC cells displayed EMT signatures such as low expression of epithelial marker E-cadherin and high expression of mesenchymal markers such as vimentin, Slug and zinc finger E-boxbinding homeobox 1 (ZEB1) [63]. Nonaka et al. found an elevated invasive ability in tumorspheres derived from RSV-M mouse glioma cells associated with the differential expression of metastatic genes [64]. In addition, tumor cells from metastatic site have been reported to be more easily engrafted in immunocompromised mice than those from the primary site. Lee et al. demonstrated that brain metastases of non-small cell lung cancer showed an increased successful rate in the establishment of patient derived xenografts (PDXs) than primary specimens [65]. Tumorspheres from these PDXs were shown to maintain their brain metastatic feature [65]. These reports illustrate the invasive property of tumorsphere cells. Tumorspheres derived from a poor differentiated human HCC cell line were determined to be resistant to several anti-cancer drugs, which was associated with the elevated expression of ATP-binding cassette sub-family G member 2 [66]. The resistance of doxorubicin was observed in mammospheres derived from MCF7 breast cancer cells and was associated with p62-mediated nuclear factor erythroid 2-related factor 2 activation [67]. These reports establish that tumorpsheres display the capability to resist therapy, which is also one of the features of CSC. The supernatant of HCT116 or HT29 colon cancer cells-derived tumorspheres stimulated the in vitro tube formation of EPCs from human umbilical cord blood through secretion of VEGF [68]. Tumor microvessel density was significantly higher in tumors derived from C6 rat glioma tumorspheres compared with cells cultured as monolayer, which was mediated by VEGF and stromalderive factor-1 secreted by tumorspheres [69]. When melanoma tumorspheres grown on Matrigel matrices, the developed laminin-associated networks were negative with the expression of CD31 and positive with CD144 indicating the feature of VM [70]. These laminin networks within melanoma tumorspheres were diminished by knockdown of nestin [70]. We previously demonstrated that mammospheres derived from human breast cancer cells displayed VM activity when plated on a Matrigel coated surface [71]. The VM activity of breast CSCs was mediated by EGF-induced Hsp27 phosphorylation [71]. These results support that tumorsphere cells could be considered as the enrichment of CSCs according to the capability to contribute to tumor vascularization

\section{TUMORSPHERES AS A RELIABLE ASSAY IN THE DEVELOPMENT OF ANTI-CANCER AGENTS}

Concepts: The discovery of anti-cancer agents is typically by examining the in vitro cytotoxic effect of rapid proliferation cancer cells in 2-dimension (2D) adherent condition. After identifying CSCs, the heterogeneity of tumor cells in response to anti-cancer agents becomes an important issue in drug screening. As described above, drug resistance is one of the main features of CSCs and a mechanism of tumor relapse. Identifying agents with anti-CSC activity has been considered as the key for a successful cancer therapy [3-5]. In addition, phenotypic heterogeneity occurs in the CSC population. For example, the markers of breast CSCs have been described as $\mathrm{CD}^{-} 4^{-} \mathrm{CD} 44^{+}[8]$ or $\mathrm{ALDH}^{\text {bright }}[10]$. CD24 ${ }^{-\mathrm{CD} 44^{+}}$cells without ALDH activity could not form tumors when xenotransplanted into mammary fat pads of NOD/SCID mice [10]. The existence of heterogeneity among CSCs indicates that analyzing the expression of CSC markers in response to potential anti-cancer agents may not a suitable assay to determine their anti-CSC activity. In contrast to 2D monolayer method or analyzing the change of CSC markers, tumorsphere assay is considered as a more reliable platform in the discovery of anti-CSC agents.

Significance: Tumorsphere assay has been widely accepted ro determine self-renewal capability in studying CSC biology. Examining the in vitro anti-self-renewal activity of potential anti-cancer agents by tumorsphere assay could reflect their in vivo anti-tumorigenic activity. Morrison et al. used proteomic analysis to compare proteome between MCF7 cells derived from tumorspheres and 2D monolayer culture and results revealed that galectin-3 was overexpressed in MCF7 tumorspheres 
[60]. N-acetyllactosamine, an inhibitor of galectin-3, both inhibited in vitro tumorsphere formation and in vivo tumorigenicity of MCF7 cells [60]. Hongisto et al. found that drug sensitivity to 102 anti-cancer compounds between 2D monolayer cultured cells and tumorspheres derived from JIMT1 breast cancer cells was different; when compared the gene expression profiles in different culture methods, tumorspheres derived from Matrigel coated surface showed most closely resembled to xenografted tumors [72]. It strongly suggests that tumorsphere assay is more suitable than 2D monolayer method in screening anti-cancer agents. Kim et al. compared the antiproliferation activity between doxorubicin and paclitaxel in carcinogen-induced primary murine tumor cells with monolayer or tumorsphere assay [73]. Two chemotherapy drugs displayed a similar anti-proliferation activity in monolayer culture; however, doxorubicin showed a better anti-proliferation activity than paclitaxel in tumorsphere assay [73]. Such differences may result from the different gene expression files between cells derived from 2D monolayer or tumorsphere method as Hongisto et al. observed [72] or the different chemical properties among compounds. Indeed, doxorubicin displayed a greater in vivo anti-tumor activity than paclitaxel when tested using tumor cell transplantation mouse model [73]. These results provide evidence to support that tumorsphere assay is a more translatable platform than 2D monolayer method in screening anti-cancer agents.

Feasibility: Established human cancer cell lines or primary tumor cells isolated from enzymatic digestion of cancer patient biopsy could be used as initial materials for CSC enrichment through tumorsphere cultivation without any background knowledge in CSC-specific markers. The cultivation of tumorspheres could be easily conducted in laboratories with their own cell culture equipment but no FACS cell sorter.

Methodology/strategy: Ultralow attachment culture surface is required for tumorsphere cultivation, which can be purchased from commercial companies or homemade by coating tissue culture plates/dishes with $1 \%$ agar [74] , polyhydroxyethylmethacrylate polymer as $12 \%(w / v)$ [75], or growth factor reduced Matrigel [72]. Although tumorsphere assay is a relatively low-cost method in screening of anti-cancer agents or in the study of CSC biology, the culture conditions of tumorsphere may influence the interpretation of the results. For example, the initial seeding cell number is important should be carefully distinguished between tumorspheres or cell aggregates. To avoid cell aggregation, filtering cell preparation is suggested with $40 \mu \mathrm{m}$ cell strainer to obtain single-cell suspension before seeding; cell density should be less than 10 cells/ $\mu \mathrm{L}$ [76]. We also recommend the addition of methylcellulose with concentration of $0.5 \%$ to $1 \%$ in tumorsphere culture medium o prevent cell aggregation. The cultivation condition of tumorsphere may be cancer type-dependent. Although the tumorsphere assay used in most studies is based on serum-free condition under the supplement of EGF and bFGF, several reports also included low concentration of serum. Cao et al. demonstrated that fetal bovine serum and $\beta$-mercaptoethanol were essential for the tumorsphere formation of mouse neuroblastoma cells derived from $M Y C N$ transgenic mice [77]. Matrigel could also be benefit in tumorsphere formation, especially for quiescent CSCs [76]. When counting the number of tumorspheres, the diameter of tumorspheres must be observed. A floating cell clump with a diameter less than $50 \mu \mathrm{m}$ should not be considered as a tumorsphere. Testing the drug effect is highly suggested by applying a secondary tumorsphere formation with dissociated single-cell suspension from primary tumorspheres. The use of a $100 \mu \mathrm{m}$ cell strainer to obtain spheres with a diameter large than $50 \mu \mathrm{m}$ is recommended for the collection of primary tumorspheres. The results of tumorsphere assay could be displayed as the changes of total number or size of formed tumorspheres. The CSC characteristics of formed tumorspheres should be determined before using the tumorsphere assay as the platform in screening anti-CSC agents. Tumorigenicity is the most important feature to be examined. Others include the expression of self-renewal-related genes (i.e. Bmi1, Oct4, Sox2, Nanog, etc.), invasive phenotype, and resistance to conventional chemotherapy drugs or radiation.

Recent progress/examples: Zhou et al. demonstrated that 8-quinolinol preferentially inhibited the sphere formation capability of MCF7 breast cancer cells and displayed a better therapeutic effect and relapse prevention when combination with paclitaxel in MCF7 xenograft mouse model [78]. By using tumorsphere assay, we have demonstrated that quercetin, a plant flavonoid compound, inhibited the self-renewal capability of HNC-CSCs through the downregulation of stemness genes (Oct4, Nanog, nestin) and mesenchymal markers (vimentin, N-cadherin, Twist) [79]. Quercetin also displayed an antiCSC activity in breast cancer cells through downregulation of Hsp27 expression [31]. We also discovered that resveratrol (3,4',5-trihydroxy-trans-stilbene), a polyphenolic compound primarily isolated from red wine, could inhibit tumorsphere formation in the in vitro and in vivo tumorigenicity of HNC-CSCs through induction of apoptosis of HNC-CSCs [63]. Wen et al. reported a phase II trial of buparlisib, a phosphatidyinositol-3 kinase inhibitor, which has been demonstrated to inhibit the growth of human glioma tumorsphere in recurrent glioblastoma patients. Buparlisib was discovered to be well-tolerated in patients and showed reduction of Akt phosphorylation in 4/6 of evaluable patients [80]. Applying Yamanaka factors to reprogram immortalized mammary epithelial cell line MCF10A, Nishi et al. recently reported a method to establish induced CSC-like cells for in vitro screening of potential anti-CSC agents [81]. Withaferin A, an Ayurvedic medicine constituent, displayed an activity 
Table 2: Application of tumorsphere assay in clinical trials ${ }^{1}$

\begin{tabular}{|l|l|l|l|}
\hline Tumor type & Status & Main application & $\begin{array}{l}\text { ClinicalTrials.gov } \\
\text { identifier }\end{array}$ \\
\hline Recurrent Glioblastoma & No specified & $\begin{array}{l}\text { Tertiary outcome } \\
\text { measures }\end{array}$ & NCT02133183 \\
\hline $\begin{array}{l}\text { Lung cancer } \\
\text { Colorectal Cancer } \\
\text { Breast Cancer }\end{array}$ & Phase II & $\begin{array}{l}\text { Generation } \\
\text { of orthotopic } \\
\text { xenograft models } \\
\text { that recapitulate } \\
\text { the parental tumor } \\
\text { behavior }\end{array}$ & NCT01483001 \\
\hline Prostate Carcinoma & No specified & $\begin{array}{l}\text { Primary outcome } \\
\text { measures }\end{array}$ & NCT02425800 \\
\hline $\begin{array}{l}\text { Recurrent High-Grade } \\
\text { Glioma }\end{array}$ & No specified & $\begin{array}{l}\text { Secondary outcome } \\
\text { measures }\end{array}$ & NCT02101905 \\
\hline Esophageal Squamous Cell Carcinoma & Phase II & $\begin{array}{l}\text { Efficacy } \\
\text { examination in pre- } \\
\text { clinical evaluation }\end{array}$ & NCT02423811 \\
\hline
\end{tabular}

${ }^{1}$ The information of listed clinical trials were obtained from the website of ClinicalTirals.gov.

in reduction of stemness and self-renewal capability, which determined by alkaline phosphatase activity and tumorsphere formation with minimal effect in cell viability by $2 \mathrm{D}$ culture and WST- 8 assay [81]. This report demonstrated the advantage of tumorsphere cultivation when compared with the 2D monolayer method in current development of anti-cancer drugs or cancer vaccine. For example, tumorsphere assay is used as one of outcome measurements in a clinical trial to evaluate the effect of mammalian target of rapamycin complex $1 / 2(\mathrm{TORC} 1 / 2)$

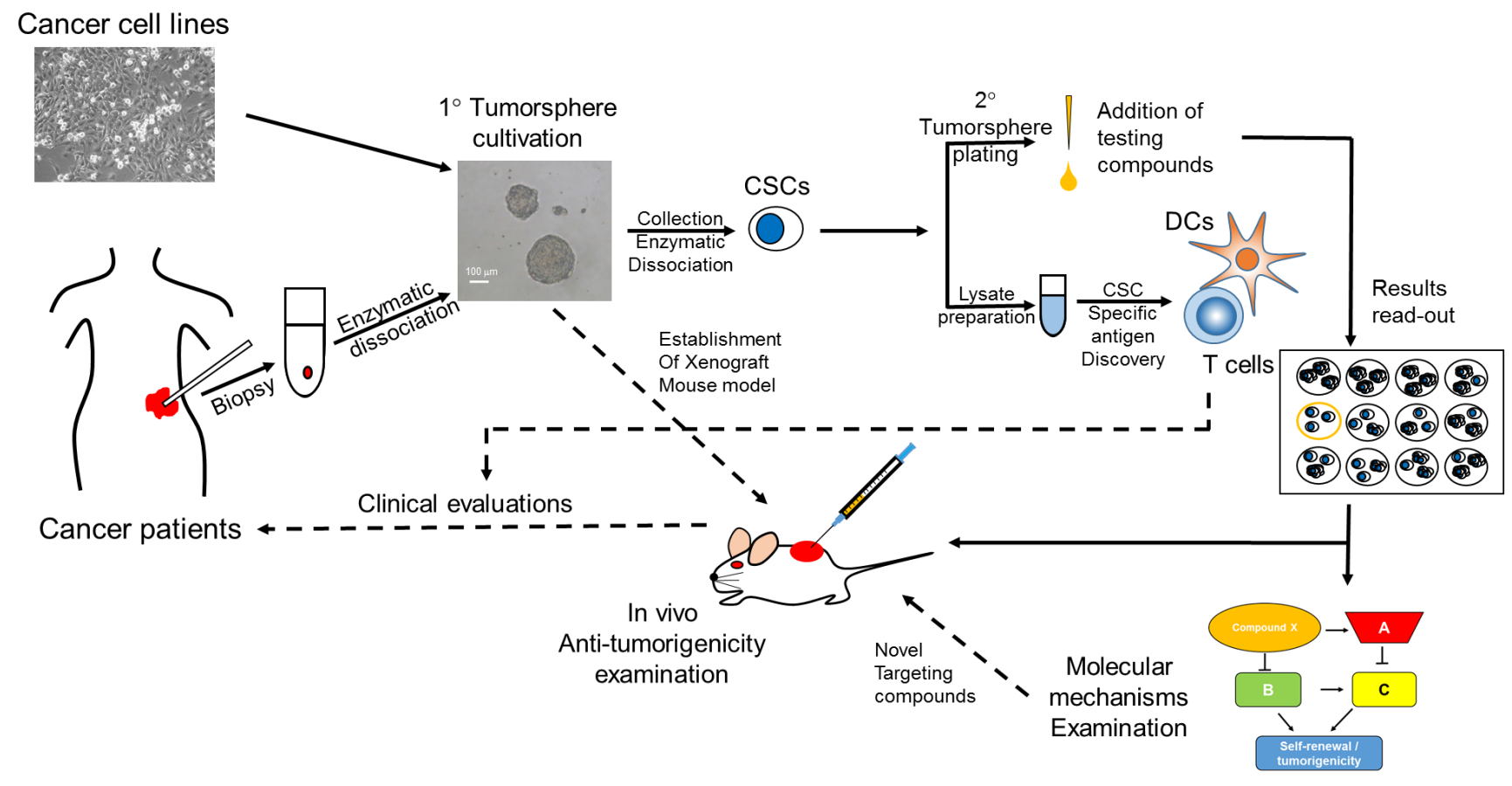

Figure 1: Suggested screening flowchart in the discovery of anti-CSC agents with tumorsphere assay. The source of primary tumorspheres can be the established cancer cell lines or primary cancer cells from enzymatic dissociated cancer tissues. Primary tumorspheres could be collected by $100 \mu \mathrm{m}$ cell strainer and processed to lysate preparation for identification of CSC-specific tumor antigens through dendritic cell presentation and $\mathrm{T}$ cell stimulating property. The primary tumorspheres could also be enzymatic dissociated into single cell suspension for secondary tumorsphere formation examination. The potential anti-CSC agents could be tested at this stage. The effects of potential agents will be determined by counting the number and/or the size of formed secondary tumorspheres. The agent with the ability to reduce secondary tumorsphere formation can be selected; the in vivo anti-tumorigenic effect of the agent can be determined; and a study on the molecular mechanisms in targeting CSCs can be conducted. Clinical evaluations can be further conducted after obtaining the results of CSC-specific antigen discovery or anti-tumor efficacy of selected anti-CSC agents. CSC, cancer stem cells; DCs, dendritic cells; $1^{\circ}$, primary; $2^{\circ}$, secondary. 
inhibitor INK128 in treating patients with recurrent glioblastoma (NCT02133183 in Table 2). Treatment of TOCR1/2 inhibitors, BEZ235 or INK128, enhanced the mammosphere formation of triple negative breast cancer cells through activation of Notch signaling pathway [82]. This finding implies that the combination of Notch and TORC $1 / 2$ inhibitors should be considered in the clinical trials of TORC1/2 inhibitors for triple negative breast cancer. The involvement of tumorsphere assay in clinical trials is summarized in Table 2 .

\section{APPLICATION OF TUMORSPHERE CULTIVATION IN THE DEVELOPMENT OF CANCER IMMUNOTHERAPY}

Recently, cancer immunotherapy is considered to provide great potential in future cancer therapy [83]. However, CSCs have been reported to escape from antitumor immunity. Schatton and Frank found that the tumorassociated antigen (TAA) MART-1 was not expressed on the surface of $\mathrm{ABCB} 5^{+}$melanoma CSCs [84]. Busse et al. compared the expression of TAAs between tumorspheres and the parental adherent cell lines and found no obvious difference in the expression of TAAs; however, the downregulation of major histocompatibility complex (MHC) molecules was observed in tumorspheres [85]. $\mathrm{Wu}$ et al. discovered that breast CSCs were resistant to the cytotoxic killing by autologous or allogenic natural killer (NK) cells which were mediated by microRNA20a-induced downregulation of MICA and MICB, two ligands for the NK activating receptor NKG2D [86]. Another report demonstrated that $\mathrm{CD} 133^{+}$glioma CSCs did not express MHC class I or NK cell activating ligands indicating that these cells were resistant to the surveillances of adaptive and innate immunity [87]. MCF7 cells that survived from NK cells-mediated antibody-dependent cell-mediated cytotoxicity showed CSC phenotypes including CD24-CD44 markers and mammosphere formation capability [88]. CSCs from transgenic adenocarcinoma of mouse prostate expressed Tenascin- $\mathrm{C}$ to inhibit $\mathrm{T}$ cell receptor restricted $\mathrm{T}$ cell proliferation by interacting with integrin $\alpha 5 \beta 1$ expressed on surface of T cells [89]. Although the immune evasion property of CSCs is being reported, other reports provided evidence that inducing CSC-specific immune responses is possible. Visus et al. using ALDHA1 peptide to generate ALDHAl-specific $\mathrm{CD}^{+} \mathrm{T}$ cells and demonstrated that these T cells killed more than 70\% of ALDH ${ }^{\text {bright }}$ cells in established human carcinoma cell lines [90]. Adoptive transfer of ALDHA1-specific T cells inhibited xenograft tumor growth in immunodeficient mice model [90]. By using tumorspheres as the source of tumor antigen, $\mathrm{Xu}$ et al. demonstrated that vaccination of dendritic cells with irradiated glioma tumorspheres increased the survival rate of mice with tumor [91]. Zhu et al. discovered an internalizing human single chain antibody with activity in binding and anti-proliferation effect to brain tumorspheres [92]. Snyder et al. recently demonstrated that the expression of podocalyxin in breast cancer cells is required for the formation of mammospheres; and podpcalyxin antibodies displayed a therapeutic potential to block tumor growth and metastasis in vivo [93]. The immune responses in against CSCs can only be studied in immunocompetent host. The identification of CSCs in murine tumor cell lines provides a good model to investigate the tumor immunology and immunotherapy of CSCs. Morrison et al. discovered that tumorspheres derived from HM-LLC murine Lewis lung carcinoma cells displayed CSC properties [60]. We have also shown that Sca-1 $1^{+}$4T1 murine breast cancer cells could formed tumorspheres and are highly tumorigenic when compared with Sca-1- counterparts [94]. The discovery of murine CSCs provides an opportunity to further understand the immunology of CSCs and develop immunotherapy to target CSCs. Recently, Xu et al. demonstrated that the expression of programmed death ligand 1 (PD-L1) was elevated in tumor-propagating cells in a mouse model of lung squamous cell carcinoma, which was induced by biallelic inactivation of Lkb1 and Pten [95]. Such results indicate that the need for testing the application of antiPD-L1 therapy in breaking down the immune suppression tumor microenvironment. Tumorsphere cultivation also provides an advantage in establishing short-term patientderived cancer cell lines for the clinical evaluation of dendritic cell-based immunotherapy. Wang et al. conducted a phase I clinical trial of immunotherapy in the treatment of HCC patients with autologous dendritic cells with patient-derived tumorspheres [96]. The efficiency rate for short-term patient-derived HCC tumor cells with tumorsphere cultivation in the clinical trial of Wang et al. was $100 \%$, whereas the successful rate using standard tissue culture techniques was only less than 50\% [96].

Figure 1 shows our view on tumorsphere assaybased discovery of anti-CSC agents. Established human cancer cell lines or primary tumor cells isolated from enzymatic digestion of cancer patient biopsy could be used as the initial materials for CSC enrichment through tumorsphere cultivation (primary tumorspheres). After the dissociation of formed primary tumorspheres, CSCs will be obtained and can be used to examine the anti-selfrenewal activity of potential agents by testing the effect in the formation of secondary tumorspheres. Agents with disruption on secondary tumorspheres formation can be selected for further examination of the antitumorigenicity activity in immunocompomised mouse model and investigation of the underlying molecular mechanisms by cDNA microarray or protein array-based pathway screening. Moreover, the enriched CSCs from primary tumorspheres can be used as the source of CSCspecific antigens. Through dendritic cell presentation and capability analysis in stimulating $\mathrm{T}$ cell proliferation/ activation, CSC-specific antigens could be identified. The 
results from in vivo anti-tumor efficacy of the selected anti-CSC agents or the identified CSC-specific antigens could be used as background knowledge for clinical evaluation trials. At this stage, tumorsphere assay could serve as one of the outcome measures.

\section{CONCLUSIONS AND FUTURE PERSPECTIVES}

For the past decades, CSCs have been identified in several types of cancers. This specific subpopulation of cancer cells participates in tumor initiation, resistance to treatment, metastasis, and tumor vascularization; the key for a success cancer therapy is to target CSCs. Cancer cells capable of forming tumorspheres share characteristics with CSCs. Such kind of cultivation method leads scientists to study the biology of CSCs without any background knowledge on CSC markers. Tumorsphere assay could also serve as a reliable platform both in the innovation of anti-CSC agents and the development of CSC-targeting immunothersapy. Several reports have been shown that the screening results from tumorsphere cultivation are more reliable than those from 2D monolayer methods $[73,81]$. Given that the immune evasion features of CSCs in some cancer types result from the downregulation of MHC molecules, enhancing the antigen presentation in CSCs must be considered during the development of CSC-targeting immunotherapy. Moreover, understanding the expression of immune checkpoint molecules, such as PD-L1 or indoleamine 2,3-dioxygenase, in tumorspheres of each cancer types can provide useful information when applying immune checkpoint therapeutics against cancers. We believe that tumorsphere assay based-drug discovery of anti-cancer agents will provide more translatable results compared with those obtained from the traditional 2D monolayer culture system.

\section{ACKNOWLEDGMENTS}

This work is supported by the Ministry of Science and Technology in Taiwan (grant No. MOST 103-2314040-015-MY3).

\section{CONFLICTS OF INTEREST}

The authors have no conflict of interest

\section{REFERENCES}

1. Hanahan D and Weinberg RA. Hallmarks of cancer: the next generation. Cell. 2011; 144:646-674.

2. Hermann PC, Bhaskar S, Cioffi M and Heeschen C. Cancer stem cells in solid tumors. Semin Cancer Biol. 2010; 20:7784.

3. Pattabiraman DR and Weinberg RA. Tackling the cancer stem cells - what challenges do they pose? Nature reviews Drug discovery. 2014; 13:497-512.

4. Ajani JA, Song S, Hochster HS and Steinberg IB. Cancer Stem Cells: The Promise and the Potential. Seminars in oncology. 2015; 42 Suppl 1:S3-S17.

5. Maccalli C and De Maria R. Cancer stem cells: perspectives for therapeutic targeting. Cancer immunology, immunotherapy. 2015; 64:91-97.

6. Bonnet D and Dick JE. Human acute myeloid leukemia is organized as a hierarchy that originates from a primitive hematopoietic cell. Nature medicine. 1997; 3:730-737.

7. Jackson M, Hassiotou F and Nowak A. Glioblastoma stemlike cells: at the root of tumor recurrence and a therapeutic target. Carcinogenesis. 2015; 36:177-185.

8. Al-Hajj M, Wicha MS, Benito-Hernandez A, Morrison SJ and Clarke MF. Prospective identification of tumorigenic breast cancer cells. Proc Natl Acad Sci U S A. 2003; 100:3983-3988.

9. Chang WW, Lin RJ, Yu J, Chang WY, Fu CH, Lai AC, Yu $\mathrm{JC}$ and $\mathrm{Yu} \mathrm{AL}$. The expression and significance of insulinlike growth factor-1 receptor and its pathway on breast cancer stem/progenitors. Breast cancer research. 2013; 15:R39.

10. Ginestier C, Hur MH, Charafe-Jauffret E, Monville F, Dutcher J, Brown M, Jacquemier J, Viens P, Kleer CG, Liu S, Schott A, Hayes D, Birnbaum D, Wicha MS and Dontu G. ALDH1 is a marker of normal and malignant human mammary stem cells and a predictor of poor clinical outcome. Cell stem cell. 2007; 1:555-567.

11. Liu TJ, Sun BC, Zhao XL, Zhao XM, Sun T, Gu Q, Yao Z, Dong XY, Zhao N and Liu N. CD133+ cells with cancer stem cell characteristics associates with vasculogenic mimicry in triple-negative breast cancer. Oncogene. 2013; 32:544-553.

12. Paldino E, Tesori V, Casalbore P, Gasbarrini A and Puglisi MA. Tumor initiating cells and chemoresistance: which is the best strategy to target colon cancer stem cells? Biomed Res Int. 2014; 2014:859871.

13. Shah A, Patel S, Pathak J, Swain N and Kumar S. The evolving concepts of cancer stem cells in head and neck squamous cell carcinoma. ScientificWorldJournal. 2014; 2014:842491.

14. Oishi N, Yamashita T and Kaneko S. Molecular biology of liver cancer stem cells. Liver Cancer. 2014; 3:71-84.

15. Crous AM and Abrahamse H. Lung cancer stem cells and low-intensity laser irradiation: a potential future therapy? Stem Cell Res Ther. 2013; 4:129.

16. Tomao F, Papa A, Strudel M, Rossi L, Lo Russo G, Benedetti Panici P, Ciabatta FR and Tomao S. Investigating molecular profiles of ovarian cancer: an update on cancer stem cells. Journal of Cancer. 2014; 5:301-310.

17. Zhan HX, Xu JW, Wu D, Zhang TP and Hu SY. Pancreatic cancer stem cells: new insight into a stubborn disease. Cancer letters. 2015; 357:429-437. 
18. Sharpe B, Beresford M, Bowen R, Mitchard J and Chalmers AD. Searching for prostate cancer stem cells: markers and methods. Stem Cell Rev. 2013; 9:721-730.

19. Siddique HR and Saleem M. Role of BMI1, a stem cell factor, in cancer recurrence and chemoresistance: preclinical and clinical evidences. Stem cells. 2012; 30:372-378.

20. Leis O, Eguiara A, Lopez-Arribillaga E, Alberdi MJ, Hernandez-Garcia S, Elorriaga K, Pandiella A, Rezola R and Martin AG. Sox2 expression in breast tumours and activation in breast cancer stem cells. Oncogene. 2012; 31:1354-1365.

21. Atlasi Y, Looijenga L and Fodde R. Cancer stem cells, pluripotency, and cellular heterogeneity: a WNTer perspective. Current topics in developmental biology. 2014; 107:373-404.

22. Tsai LL, Hu FW, Lee SS, Yu CH, Yu CC and Chang YC. Oct4 mediates tumor initiating properties in oral squamous cell carcinomas through the regulation of epithelialmesenchymal transition. PloS one. 2014; 9:e87207.

23. Phillips TM, McBride WH and Pajonk F. The response of CD24(-/low)/CD44+ breast cancer-initiating cells to radiation. Journal of the National Cancer Institute. 2006; 98:1777-1785.

24. Al-Assar O, Mantoni T, Lunardi S, Kingham G, Helleday $\mathrm{T}$ and Brunner TB. Breast cancer stem-like cells show dominant homologous recombination due to a larger S-G2 fraction. Cancer biology \& therapy. 2011; 11:1028-1035.

25. Hayashi T, Ding Q, Kuwahata T, Maeda K, Miyazaki Y, Matsubara S, Obara T, Natsugoe S and Takao S. Interferonalpha modulates the chemosensitivity of CD133-expressing pancreatic cancer cells to gemcitabine. Cancer science. 2012; 103:889-896.

26. Lee $\mathrm{CH}$, Hong HM, Chang $\mathrm{YY}$ and Chang WW. Inhibition of heat shock protein (Hsp) 27 potentiates the suppressive effect of Hsp90 inhibitors in targeting breast cancer stemlike cells. Biochimie. 2012; 94:1382-1389.

27. Oshimori N, Oristian D and Fuchs E. TGF-beta promotes heterogeneity and drug resistance in squamous cell carcinoma. Cell. 2015; 160:963-976.

28. Thiery JP. Epithelial-mesenchymal transitions in development and pathologies. Curr Opin Cell Biol. 2003; 15:740-746.

29. Mani SA, Guo W, Liao MJ, Eaton EN, Ayyanan A, Zhou AY, Brooks M, Reinhard F, Zhang CC, Shipitsin M, Campbell LL, Polyak K, Brisken C, Yang J and Weinberg RA. The epithelial-mesenchymal transition generates cells with properties of stem cells. Cell. 2008; 133:704-715.

30. Yang MH, Hsu DS, Wang HW, Wang HJ, Lan HY, Yang WH, Huang CH, Kao SY, Tzeng CH, Tai SK, Chang SY, Lee $\mathrm{OK}$ and $\mathrm{Wu} \mathrm{KJ}$. Bmil is essential in Twist1-induced epithelial-mesenchymal transition. Nature cell biology. 2010; 12:982-992.

31. Wei L, Liu TT, Wang HH, Hong HM, Yu AL, Feng HP and Chang WW. Hsp27 participates in the maintenance of breast cancer stem cells through regulation of epithelialmesenchymal transition and nuclear factor-kappaB. Breast cancer research. 2011; 13:R101.

32. Wettstein G, Bellaye PS, Kolb M, Hammann A, Crestani B, Soler P, Marchal-Somme J, Hazoume A, Gauldie J, Gunther A, Micheau O, Gleave M, Camus P, Garrido C and Bonniaud P. Inhibition of HSP27 blocks fibrosis development and EMT features by promoting Snail degradation. FASEB journal. 2013; 27:1549-1560.

33. Hermann PC, Huber SL, Herrler T, Aicher A, Ellwart JW, Guba M, Bruns CJ and Heeschen C. Distinct populations of cancer stem cells determine tumor growth and metastatic activity in human pancreatic cancer. Cell stem cell. 2007; 1:313-323.

34. Gao Y, Ruan B, Liu W, Wang J, Yang X, Zhang Z, Li X, Duan J, Zhang F, Ding R, Tao K and Dou K. Knockdown of CD44 inhibits the invasion and metastasis of hepatocellular carcinoma both in vitro and in vivo by reversing epithelialmesenchymal transition. Oncotarget. 2015; 6:7828-37. doi: 10.18632/oncotarget.3488.

35. Alvero $\mathrm{AB}, \mathrm{Fu} \mathrm{HH}$, Holmberg J, Visintin I, Mor L, Marquina CC, Oidtman J, Silasi DA and Mor G. Stemlike ovarian cancer cells can serve as tumor vascular progenitors. Stem cells. 2009; 27:2405-2413.

36. Wang R, Chadalavada K, Wilshire J, Kowalik U, Hovinga KE, Geber A, Fligelman B, Leversha M, Brennan C and Tabar V. Glioblastoma stem-like cells give rise to tumour endothelium. Nature. 2010; 468:829-833.

37. Zhang S, Zhang D and Sun B. Vasculogenic mimicry: current status and future prospects. Cancer letters. 2007; 254:157-164.

38. Wright MH, Calcagno AM, Salcido CD, Carlson MD, Ambudkar SV and Varticovski L. Brcal breast tumors contain distinct CD44+/CD24- and CD133+ cells with cancer stem cell characteristics. Breast cancer research. 2008; 10:R10.

39. Liu TJ, Sun BC, Zhao XL, Zhao XM, Sun T, Gu Q, Yao Z, Dong XY, Zhao N and Liu N. CD133(+) cells with cancer stem cell characteristics associates with vasculogenic mimicry in triple-negative breast cancer. Oncogene. 2013; 32:544-53.

40. Vasiliou V, Thompson DC, Smith C, Fujita M and Chen Y. Aldehyde dehydrogenases: from eye crystallins to metabolic disease and cancer stem cells. Chemicobiological interactions. 2013; 202:2-10.

41. Petriz J. Flow cytometry of the side population (SP). Current protocols in cytometry / editorial board, J Paul Robinson, managing editor [et al]. 2013; Chapter 9:Unit9 23.

42. Broadley KW, Hunn MK, Farrand KJ, Price KM, Grasso C, Miller RJ, Hermans IF and McConnell MJ. Side population is not necessary or sufficient for a cancer stem cell phenotype in glioblastoma multiforme. Stem cells. 2011; 29:452-461. 
43. Vlashi E, Kim K, Lagadec C, Donna LD, McDonald JT, Eghbali M, Sayre JW, Stefani E, McBride W and Pajonk F. In vivo imaging, tracking, and targeting of cancer stem cells. Journal of the National Cancer Institute. 2009; 101:350359.

44. Lagadec C, Vlashi E, Bhuta S, Lai C, Mischel P, Werner M, Henke $\mathrm{M}$ and Pajonk F. Tumor cells with low proteasome subunit expression predict overall survival in head and neck cancer patients. BMC cancer. 2014; 14:152.

45. Singh SK, Clarke ID, Terasaki M, Bonn VE, Hawkins C, Squire J and Dirks PB. Identification of a cancer stem cell in human brain tumors. Cancer research. 2003; 63:5821-5828.

46. Reynolds BA and Weiss S. Clonal and population analyses demonstrate that an EGF-responsive mammalian embryonic CNS precursor is a stem cell. Developmental biology. 1996; 175(1):1-13.

47. Weiswald LB, Bellet D and Dangles-Marie V. Spherical cancer models in tumor biology. Neoplasia. 2015; 17:1-15.

48. Ponti D, Costa A, Zaffaroni N, Pratesi G, Petrangolini G, Coradini D, Pilotti S, Pierotti MA and Daidone MG. Isolation and in vitro propagation of tumorigenic breast cancer cells with stem/progenitor cell properties. Cancer research. 2005; 65:5506-5511.

49. Collura A, Marisa L, Trojan D, Buhard O, Lagrange A, Saget A, Bombled M, Mechighel P, Ayadi M, Muleris M, de Reynies A, Svrcek M, Flejou JF, Florent JC, MahuteauBetzer F, Faussat AM, et al. Extensive characterization of sphere models established from colorectal cancer cell lines. Cellular and molecular life sciences. 2013; 70:729-742.

50. Lim YC, Oh SY, Cha YY, Kim SH, Jin X and Kim H. Cancer stem cell traits in squamospheres derived from primary head and neck squamous cell carcinomas. Oral oncology. 2011; 47:83-91.

51. Fessart D, Begueret H and Delom F. Three-dimensional culture model to distinguish normal from malignant human bronchial epithelial cells. The European respiratory journal. 2013; 42:1345-1356.

52. Watanabe Y, Yoshimura K, Yoshikawa K, Tsunedomi R, Shindo Y, Matsukuma S, Maeda N, Kanekiyo S, Suzuki N, Kuramasu A, Sonoda K, Tamada K, Kobayashi S, Saya $\mathrm{H}$, Hazama S and Oka M. A stem cell medium containing neural stimulating factor induces a pancreatic cancer stemlike cell-enriched population. International journal of oncology. 2014; 45:1857-1866.

53. Fan X, Liu S, Su F, Pan Q and Lin T. Effective enrichment of prostate cancer stem cells from spheres in a suspension culture system. Urologic oncology. 2012; 30:314-318.

54. Ramgolam K, Lauriol J, Lalou C, Lauden L, Michel L, de la Grange P, Khatib AM, Aoudjit F, Charron D, Alcaide-Loridan C and Al-Daccak R. Melanoma spheroids grown under neural crest cell conditions are highly plastic migratory/invasive tumor cells endowed with immunomodulator function. PloS one. 2011; 6:e18784.

55. Liao J, Qian F, Tchabo N, Mhawech-Fauceglia P, Beck
A, Qian Z, Wang X, Huss WJ, Lele SB, Morrison CD and Odunsi K. Ovarian cancer spheroid cells with stem celllike properties contribute to tumor generation, metastasis and chemotherapy resistance through hypoxia-resistant metabolism. PloS one. 2014; 9:e84941.

56. Yasui K, Shimamura M, Mitsutake N and Nagayama Y. SNAIL induces epithelial-to-mesenchymal transition and cancer stem cell-like properties in aldehyde dehydroghenase-negative thyroid cancer cells. Thyroid. 2013; 23:989-996.

57. Dieter SM, Ball CR, Hoffmann CM, Nowrouzi A, Herbst F, Zavidij O, Abel U, Arens A, Weichert W, Brand K, Koch M, Weitz J, Schmidt M, von Kalle C and Glimm H. Distinct types of tumor-initiating cells form human colon cancer tumors and metastases. Cell stem cell. 2011; 9:357-365.

58. Coulon A, Flahaut M, Muhlethaler-Mottet A, Meier R, Liberman J, Balmas-Bourloud K, Nardou K, Yan P, Tercier S, Joseph JM, Sommer L and Gross N. Functional sphere profiling reveals the complexity of neuroblastoma tumorinitiating cell model. Neoplasia. 2011; 13:991-1004.

59. Liu JC, Deng T, Lehal RS, Kim J and Zacksenhaus E. Identification of tumorsphere- and tumor-initiating cells in HER2/Neu-induced mammary tumors. Cancer research. 2007; 67:8671-8681.

60. Morrison BJ, Steel JC and Morris JC. Sphere culture of murine lung cancer cell lines are enriched with cancer initiating cells. PloS one. 2012; 7:e49752.

61. Kothari AN, Mi Z, Zapf M and Kuo PC. Novel clinical therapeutics targeting the epithelial to mesenchymal transition. Clinical and translational medicine. 2014; 3:35.

62. Lichner Z, Saleh C, Subramaniam V, Seivwright A, Prud'homme GJ and Yousef GM. miR-17 inhibition enhances the formation of kidney cancer spheres with stem cell/ tumor initiating cell properties. Oncotarget. 2015; 6:5567-5581. doi: 10.18632/oncotarget.1901.

63. Hu FW, Tsai LL, Yu CH, Chen PN, Chou MY and Yu CC. Impairment of tumor-initiating stem-like property and reversal of epithelial-mesenchymal transdifferentiation in head and neck cancer by resveratrol treatment. Molecular nutrition \& food research. 2012; 56:1247-1258.

64. Nonaka M, Yawata T, Takemura M, Higashi Y, Nakai E, Shimizu K and Ueba T. Elevated cell invasion in a tumor sphere culture of RSV-M mouse glioma cells. Neurologia medico-chirurgica. 2015; 55:60-70.

65. Lee HW, Lee JI, Lee SJ, Cho HJ, Song HJ, Jeong da E, Seo YJ, Shin S, Joung JG, Kwon YJ, Choi YL, Park WY, Lee HM, Seol HJ, Shim YM, Joo KM, et al. Patient-derived xenografts from non-small cell lung cancer brain metastases are valuable translational platforms for the development of personalized targeted therapy. Clinical cancer research. 2015; 21:1172-1182.

66. Hashimoto N, Tsunedomi R, Yoshimura K, Watanabe Y, Hazama S and Oka M. Cancer stem-like sphere cells induced from de-differentiated hepatocellular carcinoma- 
derived cell lines possess the resistance to anti-cancer drugs. BMC cancer. 2014; 14:722.

67. Ryoo IG, Choi BH and Kwak MK. Activation of NRF2 by p62 and proteasome reduction in sphere-forming breast carcinoma cells. Oncotarget. 2015; 6:8167-84. doi: 10.18632/oncotarget.3047.

68. Wei B, Han XY, Qi CL, Zhang S, Zheng ZH, Huang Y, Chen TF and Wei HB. Coaction of spheroid-derived stem-like cells and endothelial progenitor cells promotes development of colon cancer. PloS one. 2012; 7:e39069.

69. Folkins C, Shaked Y, Man S, Tang T, Lee CR, Zhu Z, Hoffman RM and Kerbel RS. Glioma tumor stem-like cells promote tumor angiogenesis and vasculogenesis via vascular endothelial growth factor and stromal-derived factor 1. Cancer research. 2009; 69:7243-7251.

70. Larson AR, Lee CW, Lezcano C, Zhan Q, Huang J, Fischer $\mathrm{AH}$ and Murphy GF. Melanoma spheroid formation involves laminin-associated vasculogenic mimicry. The American journal of pathology. 2014; 184:71-78.

71. Lee CH, Wu YT, Hsieh HC, Yu Y, Yu AL and Chang WW. Epidermal growth factor/heat shock protein 27 pathway regulates vasculogenic mimicry activity of breast cancer stem/progenitor cells. Biochimie. 2014; 104:117-126.

72. Hongisto V, Jernstrom S, Fey V, Mpindi JP, Kleivi Sahlberg K, Kallioniemi O and Perala M. High-throughput 3D screening reveals differences in drug sensitivities between culture models of JIMT1 breast cancer cells. PloS one. 2013; 8:e77232.

73. Kim S and Alexander CM. Tumorsphere assay provides more accurate prediction of in vivo responses to chemotherapeutics. Biotechnology letters. 2014; 36:481488.

74. Dangles-Marie V, Pocard M, Richon S, Weiswald LB, Assayag F, Saulnier P, Judde JG, Janneau JL, Auger N, Validire P, Dutrillaux B, Praz F, Bellet D and Poupon MF. Establishment of human colon cancer cell lines from fresh tumors versus xenografts: comparison of success rate and cell line features. Cancer research. 2007; 67:398-407.

75. Kim Y, Lin Q, Zelterman D and Yun Z. Hypoxia-regulated delta-like 1 homologue enhances cancer cell stemness and tumorigenicity. Cancer research. 2009; 69:9271-9280.

76. Pastrana E, Silva-Vargas V and Doetsch F. Eyes wide open: a critical review of sphere-formation as an assay for stem cells. Cell stem cell. 2011; 8:486-498.

77. Cao D, Kishida S, Huang P, Mu P, Tsubota S, Mizuno M and Kadomatsu K. A new tumorsphere culture condition restores potentials of self-renewal and metastasis of primary neuroblastoma in a mouse neuroblastoma model. PloS one. 2014; 9:e86813.

78. Zhou J, Zhang H, Gu P, Margolick JB, Yin D and Zhang Y. Cancer stem/progenitor cell active compound 8-quinolinol in combination with paclitaxel achieves an improved cure of breast cancer in the mouse model. Breast cancer research and treatment. 2009; 115:269-277.
79. Chang WW, Hu FW, Yu CC, Wang HH, Feng HP, Lan C, Tsai LL and Chang YC. Quercetin in elimination of tumor initiating stem-like and mesenchymal transformation property in head and neck cancer. Head \& neck. 2013; 35:413-419.

80. Wen PY, Wen PY, Yung WKA, Mellinghoff IK, Ramkissoon S, Alexander B, Rinne M, Colman H, Omuro AM, DeAngelis LM, Gilbert MR, DeGroot J, Cloughesy TF, Lee EQ, Nayak L, Chi AS, et al. Phase ii trial of the phosphatidyinositol-3 kinase (pi3k) inhibitor buparlisib (bkm120) in recurrent glioblastoma conducted by the ivy foundation early phase clinical trials consortium. NeuroOncology. 2014; 16:iii47.

81. Nishi M, Akutsu H, Kudoh A, Kimura H, Yamamoto $\mathrm{N}$, Umezawa A, Lee SW and Ryo A. Induced cancer stem-like cells as a model for biological screening and discovery of agents targeting phenotypic traits of cancer stem cell. Oncotarget. 2014; 5:8665-8680. doi: 10.18632/ oncotarget.2356.

82. Bhola NE, Jansen V and Arteaga C. Abstract 1945: TORC inhibitors increase the cancer stem cell (CSC) population and Notch signaling in triple negative breast cancer. Cancer research. 2014; 74:1945.

83. Couzin-Frankel J. Breakthrough of the year 2013. Cancer immunotherapy. Science. 2013; 342:1432-1433.

84. Schatton T and Frank MH. Antitumor immunity and cancer stem cells. Annals of the New York Academy of Sciences. 2009; 1176:154-169.

85. Busse A, Letsch A, Fusi A, Nonnenmacher A, Stather D, Ochsenreither S, Regenbrecht CR and Keilholz U. Characterization of small spheres derived from various solid tumor cell lines: are they suitable targets for T cells? Clin Exp Metastasis. 2013; 30:781-791.

86. Wang B, Wang Q, Wang Z, Jiang J, Yu SC, Ping YF, Yang J, Xu SL, Ye XZ, Xu C, Yang L, Qian C, Wang JM, Cui $\mathrm{YH}$, Zhang $\mathrm{X}$ and Bian XW. Metastatic consequences of immune escape from NK cell cytotoxicity by human breast cancer stem cells. Cancer research. 2014; 74:5746-5757.

87. Wu A, Wiesner S, Xiao J, Ericson K, Chen W, Hall WA, Low WC and Ohlfest JR. Expression of MHC I and NK ligands on human CD133+ glioma cells: possible targets of immunotherapy. Journal of neuro-oncology. 2007; 83:121131.

88. Reim F, Dombrowski Y, Ritter C, Buttmann M, Hausler S, Ossadnik M, Krockenberger M, Beier D, Beier CP, Dietl J, Becker JC, Honig A and Wischhusen J. Immunoselection of breast and ovarian cancer cells with trastuzumab and natural killer cells: selective escape of CD44high/CD24low/ HER2low breast cancer stem cells. Cancer research. 2009; 69:8058-8066.

89. Jachetti E, Caputo S, Mazzoleni S, Brambillasca CS, Parigi SM, Grioni M, Piras IS, Restuccia U, Calcinotto A, Freschi M, Bachi A, Galli R and Bellone M. Tenascin-C Protects Cancer Stem-like Cells from Immune Surveillance by arresting T cell activation. Cancer research. 2015; 75:2095- 
108.

90. Visus C, Wang Y, Lozano-Leon A, Ferris RL, Silver $\mathrm{S}$, Szczepanski MJ, Brand RE, Ferrone CR, Whiteside TL, Ferrone S, DeLeo AB and Wang X. Targeting ALDH(bright) human carcinoma-initiating cells with ALDH1A1-specific CD8(+) T cells. Clinical cancer research. 2011; 17:6174-6184.

91. Xu Q, Liu G, Yuan X, Xu M, Wang H, Ji J, Konda B, Black KL and Yu JS. Antigen-specific T-cell response from dendritic cell vaccination using cancer stem-like cellassociated antigens. Stem cells. 2009; 27:1734-1740.

92. Zhu X, Bidlingmaier S, Hashizume R, James CD, Berger MS and Liu B. Identification of internalizing human single-chain antibodies targeting brain tumor sphere cells. Molecular cancer therapeutics. 2010; 9:2131-2141.

93. Snyder KA, Hughes MR, Hedberg B, Brandon J, Hernaez DC, Bergqvist P, Cruz F, Po K, Graves ML, Turvey ME, Nielsen JS, Wilkins JA, McColl SR, Babcook JS, Roskelley $\mathrm{CD}$ and McNagny KM. Podocalyxin enhances breast tumor growth and metastasis and is a target for monoclonal antibody therapy. Breast cancer research. 2015; 17:46.

94. Chang WW, Kuan YD, Chen MC, Lin ST and Lee CH. Tracking of mouse breast cancer stem-like cells with Salmonella. Exp Biol Med (Maywood). 2012; 237:11891196.

95. Xu C, Fillmore CM, Koyama S, Wu H, Zhao Y, Chen Z, Herter-Sprie GS, Akbay EA, Tchaicha JH, Altabef A, Reibel JB, Walton Z, Ji H, Watanabe H, Janne PA, Castrillon DH, et al. Loss of Lkb1 and Pten leads to lung squamous cell carcinoma with elevated PD-L1 expression. Cancer Cell. 2014; 25:590-604.

96. Wang X, Bayer ME, Chen X, Fredrickson C, Cornforth AN, Liang G, Cannon J, He J, Fu Q, Liu J, Nistor GI, Cao W, Chen $\mathrm{C}$ and Dillman RO. Phase I trial of active specific immunotherapy with autologous dendritic cells pulsed with autologous irradiated tumor stem cells in hepatitis B-positive patients with hepatocellular carcinoma. Journal of surgical oncology. 2015; 111:862-7. 